\title{
The Measurement of Entrepreneurial Personality and Business Performance in Terengganu Creative Industry
}

\author{
Muhammad Abi Sofian Abdul Halim \\ Faculty of Business Management, Universiti Teknologi MARA \\ 21080 Kuala Terengganu, Terengganu, Malaysia \\ Tel: 60-13-920-4322Ｅ-mail: abisofian@tganu.uitm.edu.my
}

Associate Professor Dr Shaladin Muda

Faculty of Business and Economics, Universiti Malaysia Terengganu

21300 Kuala Terengganu, Terengganu, Malaysia

Tel: 60-19-934-6600Ｅ-mail: shaladdin@umt.edu.my

Associate Professor Dr Wan Abd Aziz Wan Mohd Amin

Faculty of Business and Economics, Universiti Malaysia Terengganu

21300 Kuala Terengganu, Terengganu, Malaysia

Tel: 60-19-988-5293Ｅ-mail: wanabdulaziz@umt.edu.my

Received: October 27, 2010 Accepted: December 9, 2010 doi:10.5539/ijbm.v6n6p183

\begin{abstract}
As the Terengganu creative industry grows from the producing sector into more complexes in industrialization, entrepreneurship will draw more attention to the need for emphasizing on creative industry. There is a vast of view to measure the factors which are affected to the growth of business performance. Thus, entrepreneurial personality becomes as a variable which have a relationship to the business performance in Terengganu creative industry. Malaysia Handicraft Development (Kraftangan Malaysia) is a government agency that taken responsibility to assists creative entrepreneurs in developing entrepreneurial characteristic and improving the business performance. According to previous literatures, several factors of entrepreneurial personality are strongly contributed to the performance of small and medium business in creative industry, such as; need for achievement, locus of control, creativity, innovative and also strategy to grab market opportunities. Therefore, the purpose of this paper is to measure the relationship of entrepreneurial personalities and business performance among Terengganu creative entrepreneurs who are engaged with the Kraftangan Malaysia, as well as in Terengganu branch. The output reveals that the result of this study is statistically significant with moderate correlation in a relationship of entrepreneurial personality and business performance. However, the partial correlation reveals that the moderating of government initiative is slightly lower correlated toward the relation of entrepreneurial personality and business performance. Finally, this study implicated two matters that should be concerned by Terengganu creative entrepreneurs once to become as a satisfaction creative entrepreneurship, there are; desire to transform the conventional thinking into a new paradigm, and; attempt to change the culture of life.
\end{abstract}

Keywords: Entrepreneurial personality, Business performance, Creative industry, Creative entrepreneurs

\section{Introduction}

The importance of entrepreneurial personality toward business performance is well recognized, as reflected an increasing number of studies devoted to entrepreneurship in recent years, for example; Shane et al, 2003; Llewelly et al, 2003; Littunen, 2000; Gartner, 1990; Bird, 1998; and McClleland, 1961. These prior studies have largely addressed what affected entrepreneurial personality and how it occurs. However, in order to develop 
entrepreneurial personality as empirical study in Malaysia Handicraft development Agency (Kraftangan Malaysia) that subsequently allows appropriate intervention from this agency perspective, it is necessary to further investigate the attributes involved in entrepreneurial personality through a framework which has close connections with business performance.

The creative industries are a new practicing in Malaysia to establish in several sector, and which relate to the needs of idea to develop arts-making through entrepreneurship. It provides a unique opportunity for designers, artists, filmmakers, researchers, educators and entrepreneurs to easily connect and collaborate with others to create new work and develop new product ideas in creative industries. However, most of Malaysia creative entrepreneurs are not really achieving personality traits in a context of entrepreneurship. In fact, some of them are not really confident to face challenges in creative industry. Additionally, there are still depending on the government initiative to assists the product selling, financial, operation and also guiding in their business management (Hatta Azad Khan, 2006).

Therefore, the purpose of this paper is first; to identify the significant relationship of entrepreneurial personality toward the business performance, and secondly; is to study the significance of government initiative as a moderator in a relationship of entrepreneurial personality and business performance. Meanwhile, the scope of this study is to measure the factors in entrepreneurial personality toward the significance relation with the business performance among Terengganu creative entrepreneurs who are registered with Kraftangan Malaysia, Terengganu.

\section{Entrepreneurial Personality in Terengganu Creative Industry}

The definition of entrepreneurial personality refer to the individual who have the ability to take risk, innovativeness, knowledge of the market functions, marketing skills and business management skills; which are influence to the personality traits in a context of cooperation, networking, and also independent in business (Littunen, 2000). Meanwhile, the term of entrepreneurial personality in this study describe the individual who are highly motivation in a factor of; need for achievement, locus of control, creative, innovative and grab market opportunities (Stevenson \& Gumpert, 1983; McClleland, 1961; Shane et al, 2003; Rotter, 1966). Nevertheless, recent research showed that the creative entrepreneurs are much more artistic and creativity reliant than other factors in entrepreneurial characteristics (Ghouse, 2008). As well as to develop the creative entrepreneurs toward idealistic, innovation and strategic, Kraftangan Malaysia, Terengganu has taken responsibility to accommodate facilities, technology, and workshop training program. The aim of this agency is to develop the skill and sense of entrepreneurship among creative entrepreneurs in Terengganu, in term of innovative, creative, independent, risk taking, and problem solving.

Previously, creative industry become as a main sector in United kingdom which is contributed to the gross domestic product in economy, where the growing rate is faster than any other economic sector in a year of 1997 to 2003 (Einarsson, 2002). Terengganu has vast of cultural and creative resources in the fields of performing arts, visual and fine arts, Islamic calligraphy, film, arts education, literary works and craft which can be further developed and exploited as well as in United Kingdom. Ministry of Unity, Arts, Culture and Heritage takes responsibility to ensure the implementation of creative industry in Malaysia becomes reality (Rais Yarim, 2006). Therefore, an emphasizing of entrepreneurial characteristic in a Malaysia, particularly Terengganu creative industry becomes essential in developing personality traits which is contributed to the business performance.

\section{The Indicators and Variables}

Entrepreneurial personality can be seen as underlying characteristic that are causally related to effective business performance (Litunen, 2000). It is a multi-dimensional construct constituted from different components, such as; need for achievement (McClleland, 1961), locus of control (Rotter, 1966), creativity (Marcus, 2005), innovative (Littunen, 2000) and grab market opportunities (McClleland, 1961). Table 1 represents indicators for each variable in entrepreneurial personalities which are key factors affecting the development of business performance. Furthermore, government initiative became as a moderating variable to study the significance changing toward the association of entrepreneurial personality and business performance.

\section{Hypothesis and Theoretical Framework}

The first aim of this study is to investigate whether a better personality in entrepreneurship will affect to business performance or vice versa. Based on these theoretical starting points, the first research hypothesis is framed as follows;

H1: There would be a significance relationship between entrepreneurial personality and business performance.

Furthermore, this study also investigates the role of government initiative as a supportive action to the 
association of entrepreneurial personality and business performance. Therefore, the second hypothesis is framed as follows;

H2: There would be a significant changing between entrepreneurial personality and business performance if government initiative become as a moderator.

As well as to discuss the hypothesis of this study, the theoretical framework becomes essential to visualize the combination of independent variables, dependent variable, and moderating variable in developing of two hypothesis. Figure 1 represents the relationship of factors of entrepreneurial personality (e.g. need for achievement, creativity, innovative, locus of control, and grab market opportunities), business performance, and government initiative.

\section{Methodological}

Since this study is aimed at addressing the phenomenon of entrepreneurial personality affected to the business performance, a quantitative approach with designing of questionnaire was adopted so that investigating the variables was made possible.

As part of this study is involved several crafts products in Kraftangan Malaysia, Terengganu (e.g. batik, ceramics, wood carving, forest based craft, metal, and songket), researcher has used the stratified random sampling to clarified each of creative products in the total populations. Around 309 local creative entrepreneurs have been registered under Kraftangan Malaysia, Terengganu and have trained a wide range of entrepreneurship. Meanwhile, there are 107 set of questionnaire was distributed to the creative entrepreneurs in Terengganu. However, there are only 105 respondents were replied the questionnaire represented a diversity of product categories. Then, the data was entered and analyzed with the Statistical Package for Social Sciences (SPSS) software program (version 16.0). Table 2 shows the number of population and sample in this study.

\section{Data Analysis and Finding}

As part of this research is to study the significance relationship between variables in theoretical framework, bivariate correlation was used to test the $H 1$ and partial correlation used to test the $H 2$ in this study. However, a descriptive analysis was first conducted before inferential analysis in order to analyses the frequency and percentage of demographic in entrepreneurial and business profile. Furthermore, this analysis was divided into four parts, including; the reliability analysis, descriptive analysis on demographic profile, the relationship of entrepreneurial personality and business performance $(H 1)$, and government initiative as a moderating variable in a relationship of entrepreneurial personality and business performance $(\mathrm{H} 2)$.

\subsection{Reliability Analysis}

Based on the reliability analysis, it indicates that most of the variables that has been investigated in this study are found to be highly reliability, such as; need for achievement (0.822), locus of control (0.761), creativity (0.785), innovative (0.796), grab market opportunities (0.816), business performance (.0939) and government initiative $(0.950)$, as well as mention in a table 3. It means that the structure of questionnaire in this study is well consistence. Table 3 shows the result of reliability of this study.

\subsection{Descriptive Analysis on entrepreneurial Profile}

A frequency and percentage of respondents in each part of entrepreneurial profile was depicted in table 4 (demographic profile) and 5 (business profile). In term of demographic profile, most of creative entrepreneurs in Kraftangan Malaysia Terengganu are age in between 31 - 45 (43.8\%) and follow by age of $46-55(29.5 \%)$ and the rest are below $20 \%$. In term of gender, the majority of creative entrepreneurs are male $(61 \%)$ and female (39\%). Meanwhile, marital status has shown that is $78.1 \%$ are married, $12 \%$ are widow and only $10.5 \%$ are bachelor. Those operating in creative business form, the majority of their field study are business background (58.1\%), arts (35.2\%), social science (4.8\%), and science and technology (1.9\%). In term of level of education, the highest contribution is from school which equal to $34.3 \%$, and followed by certificate holder (27.6\%), diploma holder (26.7\%), degree holder (10.5\%) and master/PhD holder (1.0\%).

In term of business profile, the result in Table 5 clearly shows that the majority of creative entrepreneurs who are registered in Kraftangan Malaysia Terengganu are those operated their business in city area (55.2\%), followed by town area $(38.1 \%)$, and village $(6.7 \%)$. In term of business types, there are $60.0 \%$ of total respondents are involved in sole proprietorship, $24.8 \%$ are involved in private limited, and only $15.2 \%$ are operated in partnership. Meanwhile, the market size has shown that most of respondents marketed their product in a stated level (44.0\%), followed by national level (36.0\%), district level $(17.0 \%)$ and only $3.0 \%$ for international level.

Furthermore, the term of operations has indicated that $42.9 \%$ of respondents are operated in between $11-20$ 
years of operations, $23.8 \%$ in between $6-10$ years, $21.0 \%$ are operated more than 21 years, and only $12.4 \%$ are operated less than 5 years. In term of types of products producing, the highest level of product producing is a batek product (31.4\%), followed by silver product (14.0\%), 13.0\% for wood carving, forest-based, pewter, and songket, $3.0 \%$ for crystal, $2.0 \%$ for ceramic, and $1.0 \%$ for leather. All results are shown in table 5 below.

\subsection{Hypothesis 1: Relationship of entrepreneurial personality and business performance}

Entrepreneurial personality become as a major independent variable which comprises five minor supportive variables (e.g. need for achievement, locus of control, creativity, innovative, grab market opportunities) to looks the significance relationship with the business performance. Generally, the first conducted of this analysis is to test the hypothesis 1 , and followed by the measurement of correlation of each factors in entrepreneurial personality toward business performance.

The results indicate that there was a statistically significant association between entrepreneurial personality (major independent) and business performance with $\mathrm{r}=0.649$ and $\mathrm{p}=0.000$. The output reveals that the results of this study are moderately significance relationship. Therefore, we accept the hypothesis and also can be interpreted that most of entrepreneur in Kraftangan Malaysia Terengganu are moderately have a sense of entrepreneurship which are contributed to the business performance. These results also supported the literature of this study as claimed by Littunen (2000), McClelland (1961), Rotter (1966), Marcus (2005), Drucker (1988), Bird (1989), and Bechetti \& Trovoto (2002).

Additionally, there are only two factors of entrepreneurial personality indicate that are moderate correlation with business performance, there are; grab market opportunities $(\mathrm{r}=0.564, \mathrm{p}=0.000)$ and Locus of Control $(\mathrm{r}=0.563$, $\mathrm{p}=0.000$ ), However, others factors of entrepreneurial personality are not really strong exist but still have a relationship, such as; innovative $(\mathrm{r}=0.482, \mathrm{p}=0.001)$, creativity $(\mathrm{r}=0.451, \mathrm{p}=0.005)$, and need for achievement $(\mathrm{r}=0.376, \mathrm{p}=0.042)$. Table 6 mentions the results of coefficient correlations and significance value.

\subsection{Hypothesis 2: Government initiative as a moderating variable}

Kraftangan Malaysia is a Malaysian government agency which is under Ministry of Unity, Information and Culture. Kraftangan Malaysia Terengganu is a departments of this agency which is responsible to develop the creative industry in Terengganu, such as; human capital development, industrialization, technology development, and also entrepreneurship. Therefore, Kraftangan Malaysia Terengganu plays an importance role to realize the development of entrepreneurship in Terengganu creative industry. Consequently, an initiative of government become as a moderating variable in this study to measure the effective action that has been done by government toward the development of entrepreneurial personality and business performance.

The findings indicate that moderating of government initiatives (Kraftangan Malaysia) was statistically significant in an association of entrepreneurial personality and business performance with $r=0.438$ and $p=0.000$. Therefore, the result of hypothesis 2 appears that the moderating of government initiative is weakly moderate in the relationship of entrepreneurial personality and business performance; however, it is still significance. This finding also agreed with the argument of previous literature, as claimed by; Wan Hashim Wan The (1995), Rais Yatim (2006), and Hatta Azad Khan (2006). Furthermore, these findings also supported by the result of diminished significance relationship of variables, such as; locus of control $(r=0.446, p=0.002)$, innovative $(\mathrm{r}=0.304, \mathrm{p}=0.006)$, need for achievement $(\mathrm{r}=0.224, \mathrm{p}=0.037)$ and also creativity $(\mathrm{r}=0.293, \mathrm{p}=0.043)$. However, the factor of grab market opportunities (independent variables) is keep in existence in the similar results as hypothesis $1(\mathrm{r}=0.564, \mathrm{p}=0.000)$. All results are shown in a table 7 .

Furthermore, these findings can be interpreted that some of creative entrepreneurs in Terengganu have not taken the opportunities that was accommodated by Kraftangan Malaysia Terengganu, such as; entrepreneurship training and development, business facilities, financial assistance, business chain, and marketing. In fact, some of them are never known the opportunities that were offered by government previously (Wan Hashim Wan The, 1996). In addition, Rais Yatim (2006) was mentioned that some of creative entrepreneurs are still depending on others government ministries (e.g. Ministry of Entrepreneurship Corporation Development, Ministry of Rural Area development) which are contribute to the entrepreneurial policies planning, business assisting, and legal action of creative industry.

\section{Implication and Recommendation}

Currently, arts-making has been defined as activities which are highly contributed to the business opportunities as well as in creative industry (Wan Hashim Wan The, 1996; Hatta Azad Khan, 2006; Rais Yatim, 2006). Additionally, an initiative of Malaysia government become a platform for those practitioners to develop their entrepreneurial personality toward business performance, such as; need for achievement, locus of control, 
creativity, innovative, grab market opportunities. According to the result of hypothesis 1, the relationship of entrepreneurial personality in Kraftangan Malaysia Terengganu has a moderate correlation toward the business performance $(\mathrm{r}=0.649, \mathrm{p}=0.000)$. However, hypothesis 2 has shown that most of Terengganu creative entrepreneurs are not really aware the opportunities that was offered by government. Therefore, these findings implicated that are two matters should be concerned by Terengganu creative entrepreneurs once they want to become a qualified creative entrepreneurs; there are; desire to transform the conventional thinking into a new paradigm, and; attempt to change the culture of life.

\subsection{Desire to shift the conventional thinking into an entrepreneurial paradigm}

As well as to embracing the creative industry become competitive, the practicing of paradigm shift in entrepreneurship become as a factor to influencing creative industry to become growth, sustainability and organizational development. The major focus of creative entrepreneurs is the issue of entrepreneurial personality development which shifting their paradigm in business perceptions. Certainly, creative entrepreneurs should shift their paradigm from artistic-based performance into entrepreneurial-based performance to activate their business performance and also to explore the creative industry as a major contribution to Malaysian economy. Therefore, Terengganu creative entrepreneurs also should take initiative to develop their own personality traits in term of capable to take challenging task, problem solving, self-confidence, ability to influence events, capable to study market environment, and also creating a new business strategic.

This implication also agreed with the argument by Wan Hashim Wan Teh (1996), Hatta Azad Khan (2006), and Rais Yatim (2006) who was mentioned that creative entrepreneurs need to shift their paradigm to become entrepreneurial traits, in term of profit-oriented and competitive-oriented. According to table 8 (Paradigm shift of creative entrepreneurs in creative industry) that was highlighted by Wan Hashim Wan Teh (1996), Hatta Azad Khan (2006), and Rais Yatim (2006), there are six indicators that should aware by creative entrepreneurs in entrepreneurial paradigm, such as; independently, motivated in arts and business, product focus on customers' appreciation, creative and innovative, profit oriented, and product-value depending on customer perceptions.

\subsection{Attempt to change the culture of life}

According to Hatta Azad Khan (2006), some of Malaysian creative entrepreneurs are not realize their thinking toward the vision and mission of the business, strategic planning, develop competitive advantage, and the market characteristics. In other words, there are ignoring the achievement of their business in a context of looking a better business improvement, challenging, and set the target. Furthermore, this result implicate that creative entrepreneurs should change their business culture in a context of business value, thinking and believing. The practicing of cultural changing in a business management is to change the business philosophy which is directly affected to the vision, planning, and implementation of business strategic. Schaefer (1989) has highlighted that the study of cultural change in sociology included the changing of values of thinking, ideas, customs, and social system of community in their life. The changing concept of business culture in this study is to change the culture of self-satisfaction toward the business into customer satisfaction. Therefore, the finding of this study has implicated that Terengganu creative entrepreneurs should attempt to change of their culture of life in a context of thinking, value, believing, and custom.

\section{Conclusion}

In summary, the term of entrepreneurial personality of this study discovered several personality traits, such as; need for achievement, locus of control, creative, innovative, and grab the market opportunities. This quantitative analysis reveals that the factors of entrepreneurial personality are significance associated with the business performance. Consequently, the significance results have suggested that the creative entrepreneurs should shift their paradigm to become more entrepreneurial characteristics and also change their culture in a context of art-based performance into entrepreneurial- based performance. Beside that, creative entrepreneurs should change their culture of life to become more on profit and customer oriented.. Therefore, the result of this study can be realize that a good creative entrepreneurs is individual who are ability take challenge, competitive, strategic and highly desire in business achievement.

Furthermore, government also should take initiative to specified and structure their policies in development of entrepreneurial personality, as well as that they have implemented in developing of entrepreneurial skill and knowledge in an entrepreneurial development program previously. Therefore, the solution and finding of this study will applicable to a wide range of creative industry in Malaysia that can increase the level of activities in arts field into a new dimension. 


\section{References}

Becchetty, L., \& Trovato, G. (2002). The Determinants of Growth for Small and Medium Sized Firm. The Role of the Availability of External Finance. Small Business Economics, 2(4), 53-65

Bird, B. (1989). Entrepreneurial Behavior. London: Glenview.

Einarsson, A. (2002). Entrepreneurship as a Part of the Creative Industries within the Cultural Sector in a Small Society. Review of International Comparative Management, 1(13), 208-229.

Gartner, W.B. (1990). Some Suggestions for Research on Entrepreneurial Traits and Characteristics. Entrepreneurship Theory and Practice, 5(2), 15-28.

Ghouse, N. M. (2008). Seni Tempatan Wajar Memasuki Babak Industri, Ceramah Pesona Seni Aswara di Aswara, Kuala Lumpur.

Hatta Azad Khan. (2006). Creative and Cultural Industries in a Context of Globalization. Procedding paper for Conference of Cultural Arts, Heritage and Arts Education in 21st. Century: Theory and Practice, PWTC, Kuala Lumpur.

Littunen, H. (2000). Entrepreneurship and the Characteristics of the Entrepreneurial Personality. International Journal of Entrepreneurial Behavior \& Research, 6(6), 103-121.

Llewellyn, D.F., \& Wilson, K.M. (2003). The Controversial Role of Personality Traits in Entrepreneurial Psychology. Journal of Education and Training, 45(6), 96-123.

McClelland, D.C. (1961). Characteristics of Successful Entrepreneurs. Journal of Creative Behavior, 21(3), 53-67.

Rais Yatim. (2006). Ministry of arts, Culture and Heritage: Keynote address in Opening Ceremony of Conference of Cultural Arts, Heritage and Arts Education in 21st. Century: Theory and Practice, PWTC, Kuala Lumpur.

Rotter, J. B. (1966). Generalized expectancies for internal versus external control of reinforcement. Psychological Monographs: General and Applied, 80(1), 1-28.

Schaefer, R.T. (1989). Sociology. New York: McGraw-Hill

Shane, S., Locke, E.A., \& Collins, C.J. (2003). Entrepreneurial Motivation. Human Resources Management Review, 13(5), 86-102.

Stevenson, H. (1983). A Perspective on Entrepreneurship. Harvard Business School Working Paper, 9(21), 384-131.

Wan Hashim Wan The. (1996). Malay Handicraft Industries: Origins and Development. Kuala Lumpur: Dewan Bahasa \& Pustaka. 
Table 1. Indicators for each variable

\begin{tabular}{|c|c|c|}
\hline Variables & Indicators & Citation \\
\hline $\begin{array}{l}\text { Need for } \\
\text { Achievement }\end{array}$ & $\begin{array}{l}\text { i. Looking for a better improvement } \\
\text { ii. Capable to challenging task } \\
\text { iii. Set the target through own effort } \\
\text { iv. Problem Solving }\end{array}$ & $\begin{array}{l}\text { Littunen, 2000; } \\
\text { McCleland, } 1961\end{array}$ \\
\hline Locus of Control & $\begin{array}{l}\text { i. Capable to control one's own life } \\
\text { ii. Self-confidence } \\
\text { iii. Ability of entrepreneurs to influence events } \\
\text { iv. Capable to turning thoughts into action }\end{array}$ & $\begin{array}{l}\text { Rotter, 1966; } \\
\text { Littunen, } 2000\end{array}$ \\
\hline Creativity & $\begin{array}{l}\text { Creativity is the key value of entrepreneurship } \\
\text { Capable to develop new product } \\
\text { Capable to differentiate product } \\
\text { Create strategic planning and implementation }\end{array}$ & Marcus, 2005 \\
\hline Innovative & $\begin{array}{l}\text { i. Develop current product performance } \\
\text { ii. Develop current production } \\
\text { iii. Create new source of supply } \\
\text { iv. Create new structure in management }\end{array}$ & $\begin{array}{l}\text { Littunen, 2000; } \\
\text { Bird, 1989; } \\
\text { Drucker, } 1988\end{array}$ \\
\hline $\begin{array}{l}\text { Grab Market } \\
\text { Opportunities }\end{array}$ & $\begin{array}{l}\text { Capable to study market environment } \\
\text { Strong character to face competitors } \\
\text { Strategic to grab opportunities based on strength }\end{array}$ & McClelland, 1961 \\
\hline $\begin{array}{l}\text { Business } \\
\text { Performance }\end{array}$ & $\begin{array}{l}\text { i. } \text { Business growth } \\
\text { ii. Profitability } \\
\text { iii. Competitive advantage } \\
\text { iv. Manageable }\end{array}$ & $\begin{array}{l}\text { Bechetti \& Trovoto. } \\
2002\end{array}$ \\
\hline $\begin{array}{l}\text { Government } \\
\text { Initiative }\end{array}$ & 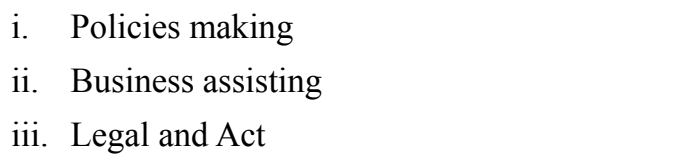 & $\begin{array}{l}\text { Hatta Azad Khan, 2006; } \\
\text { Wan Hashim Wan Teh, } \\
1996\end{array}$ \\
\hline
\end{tabular}

Table 2. Population and sample size

\begin{tabular}{|l|r|r|r|r|}
\hline \multirow{2}{*}{ Producers } & \multicolumn{2}{|c|}{ Population } & \multirow{2}{*}{ Sample } & \multirow{2}{*}{ Replied } \\
\cline { 2 - 3 } & Frequency & \multicolumn{1}{c|}{$\%$} & & \\
\hline Batik & 97 & 31.2 & 33 & 33 \\
\hline Ceramic & 6 & 1.8 & 2 & 2 \\
\hline Wood Carving & 37 & 12.1 & 13 & 13 \\
\hline Forest based fiber & 37 & 12.1 & 13 & 13 \\
\hline Pewter & 37 & 12.1 & 13 & 13 \\
\hline Songket & 37 & 12.1 & 13 & 13 \\
\hline Silver & 40 & 13.0 & 14 & 14 \\
\hline Crystal & 9 & 2.8 & 3 & 3 \\
\hline Leather & 9 & 2.8 & 3 & 1 \\
\hline Total & 309 & 100.0 & 107 & 105 \\
\hline
\end{tabular}


Table 3. Reliability Analysis of Variables

\begin{tabular}{|l|c|c|c|}
\hline \multicolumn{1}{|c|}{ Section } & $\begin{array}{c}\text { Number } \\
\text { of Cases }\end{array}$ & $\begin{array}{c}\text { Number } \\
\text { of Item }\end{array}$ & $\begin{array}{c}\text { Reliability } \\
\text { Coefficients } \\
\text { ALPHA }\end{array}$ \\
\hline Need for Achievement & 105 & 13 & 0.822 \\
\hline Locus of Control & 105 & 12 & 0.761 \\
\hline Creativity & 105 & 18 & 0.785 \\
\hline Innovative & 105 & 13 & 0.796 \\
\hline Grab Market Opportunities & 105 & 12 & 0.816 \\
\hline Business Performance & 105 & 30 & 0.939 \\
\hline Government Initiative & 105 & 15 & 0.950 \\
\hline
\end{tabular}

Table 4. Demographic Profile

\begin{tabular}{|c|c|c|c|c|c|}
\hline Items & Frequency & Percentage & Items & Frequency & Percentage \\
\hline \multicolumn{3}{|l|}{ Gender } & \multicolumn{3}{|c|}{ Level of Education } \\
\hline Male & 64 & 61.0 & School & 36 & 34.3 \\
\hline Female & 41 & 39.0 & Certificate & 29 & 27.6 \\
\hline Total & 105 & 100.0 & Diploma & 28 & 26.7 \\
\hline \multicolumn{3}{|c|}{ Marital Status } & Degree & 11 & 10.5 \\
\hline Bachelor & 11 & 10.5 & Master/PhD & 1 & 1.0 \\
\hline Married & 82 & 78.1 & Total & 105 & 100.0 \\
\hline Widow & 12 & 11.4 & \multicolumn{3}{|l|}{ Field of Study } \\
\hline Total & 105 & 100.0 & Business & 61 & 58.1 \\
\hline \multicolumn{3}{|l|}{ Age } & Science \& Tech & 2 & 1.9 \\
\hline Below 18 & 2 & 1.9 & Social Science & 5 & 4.8 \\
\hline $19-30$ & 10 & 9.5 & Arts & 37 & 35.2 \\
\hline $31-45$ & 46 & 43.8 & Total & 105 & 100.0 \\
\hline $46-55$ & 31 & 29.5 & & & \\
\hline 56 above & 16 & 15.2 & & & \\
\hline Total & 105 & 100.0 & & & \\
\hline
\end{tabular}


Table 5. Business Profile

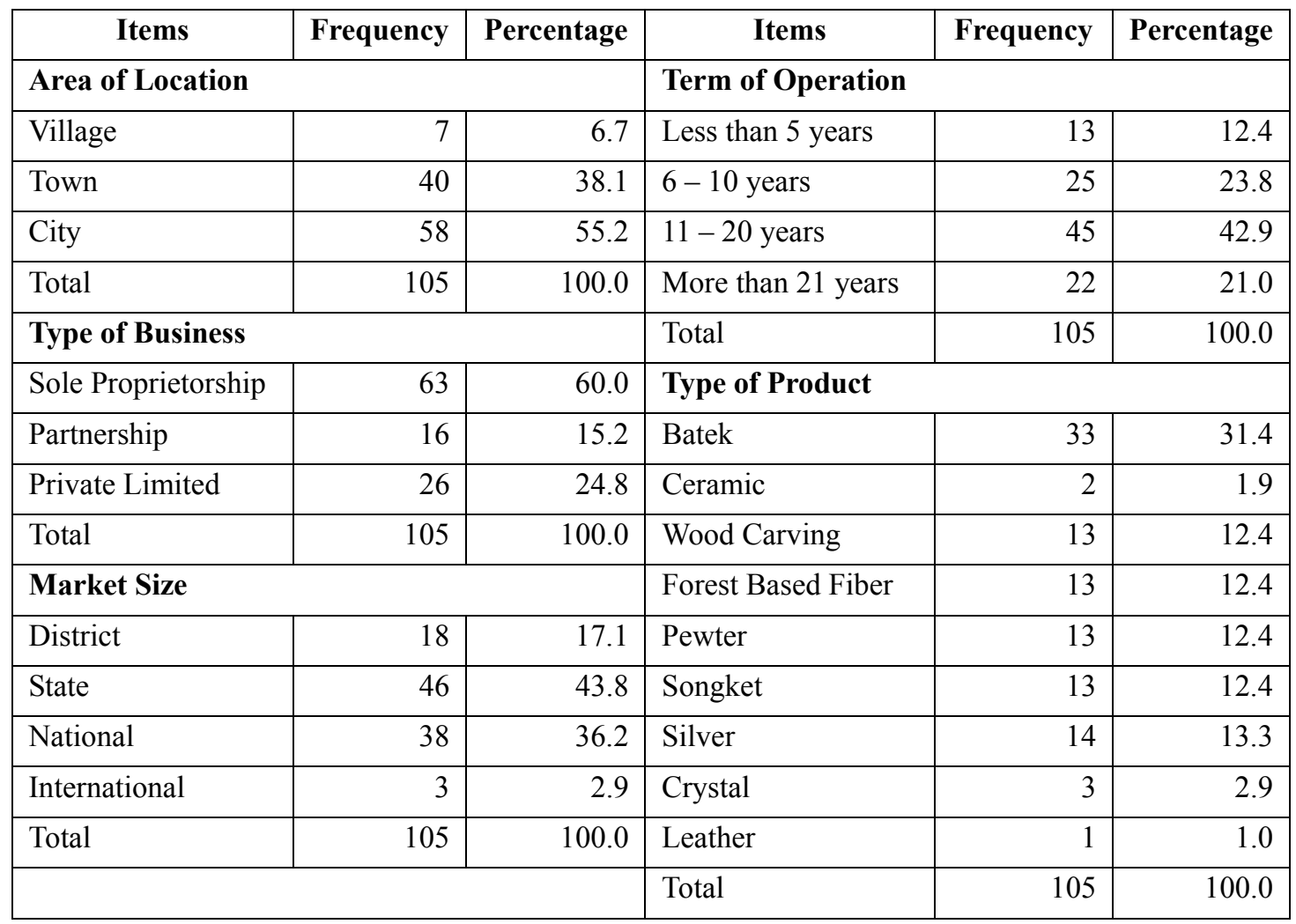

Table 6. Coefficient Correlations and Significance Value

\begin{tabular}{|l|c|c|c|}
\hline \multicolumn{1}{|c|}{ Independent Variables } & Significance & $\begin{array}{c}\text { Bivariate } \\
\text { Correlation }\end{array}$ & Level of Correlation \\
\hline Need for Achievement & 0.042 & 0.376 & Weakly moderate \\
\hline Locus of Control & 0.000 & 0.563 & Moderate \\
\hline Creativity & 0.005 & 0.451 & Weakly moderate \\
\hline Innovative & 0.001 & 0.482 & Weakly moderate \\
\hline Grab Market Opportunities & 0.000 & 0.564 & Moderate \\
\hline
\end{tabular}

Table 7. The Partial Correlation Result

\begin{tabular}{|l|c|c|c|}
\hline \multicolumn{1}{|c|}{ Independent Variables } & Significance & $\begin{array}{c}\text { Partial } \\
\text { Correlation }\end{array}$ & Level of Correlation \\
\hline Need for Achievement & 0.037 & 0.224 & Very weak moderate \\
\hline Locus of Control & 0.002 & 0.466 & Weakly moderate \\
\hline Creativity & 0.043 & 0.293 & Very weak moderate \\
\hline Innovative & 0.006 & 0.304 & Weakly moderate \\
\hline Grab Market Opportunities & 0.000 & 0.564 & Moderate \\
\hline
\end{tabular}


Table 8. Paradigm shift of creative entrepreneurs in Malaysia creative industry

\begin{tabular}{|l|l|}
\hline \multicolumn{1}{|c|}{$\begin{array}{c}\text { Conventional Thinking } \\
\text { (Artistic-based Performance) }\end{array}$} & \multicolumn{1}{c|}{$\begin{array}{c}\text { Entrepreneurial Paradigm } \\
\text { (Entrepreneurial-based Performance) }\end{array}$} \\
\hline 1. Dependent & 1. Independent \\
\hline 2. Arts motivated & 2. Business and art motivated \\
\hline 3. Self-appreciation & 3. Consumer-appreciation \\
\hline 4. Creative & 4. Creative \& Innovative \\
\hline 5. Social oriented & 5. Profit oriented \\
\hline 6. Product value depend on producer & 6. Product value depend on customer \\
\hline
\end{tabular}

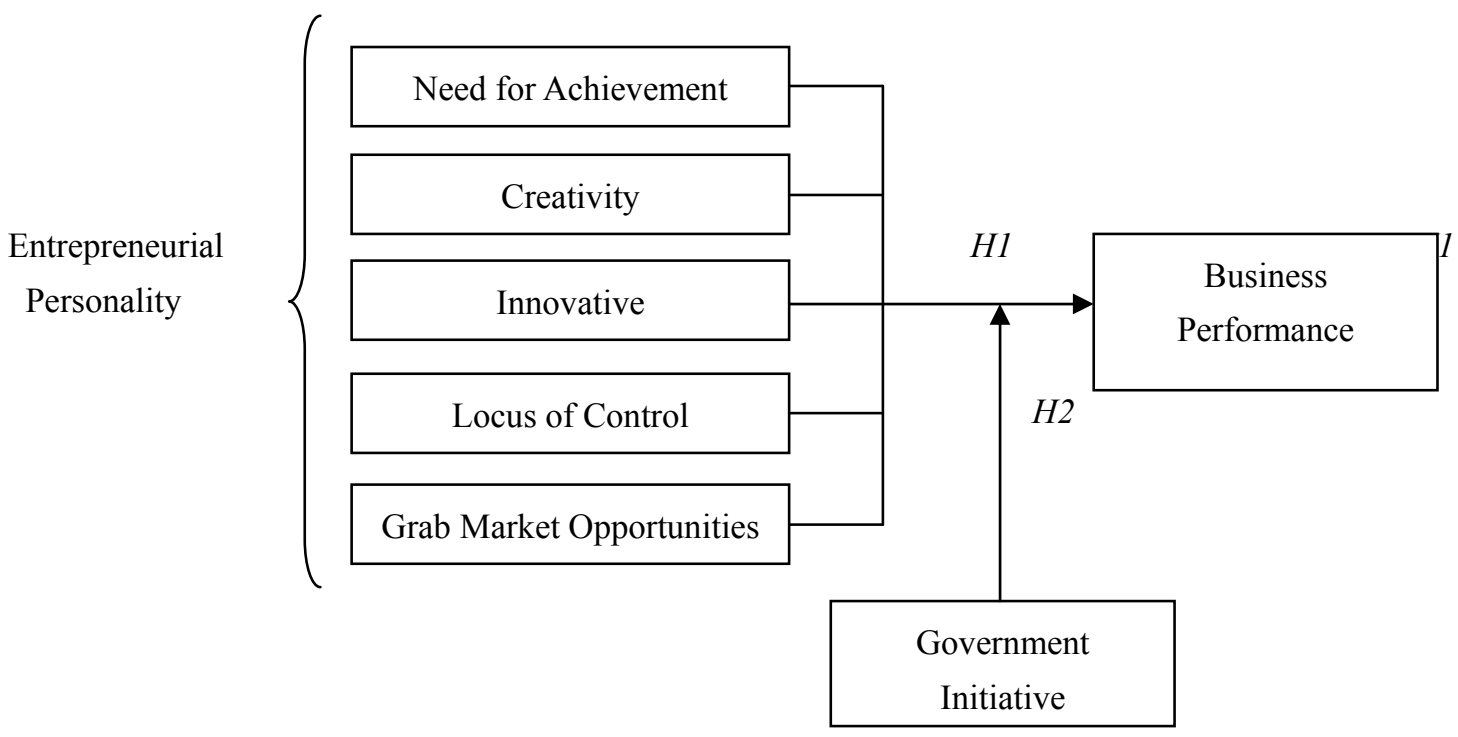

Figure 1. Theoretical Framework of Entrepreneurial Personality and Business Performance 